\title{
Turn of the Month Effect in Indian Metal Sector with Special Reference to BSE Metal Index
}

\author{
J. Sudarvel and Dr.R. Velmurugan
}

\begin{abstract}
This study investigates the existence of a Turn of the Month Effect in India's Metal sector. The study uses the daily return data of the Bombay Stock Exchanges (BSE) Metal Index for the period ranging between April 2004 and March 2015. The collected data have been analysed by making use of descriptive statistics and paired ' $t$ " test. The outcomes confirm the presence of seasonality in stock returns and the Turn of the Month Effect. The findings are also reliable with the Turn of the Month Effect which exists in the BSE Metal index. The results of the study imply that the stock market in India, especially in the Metal sector is inefficient, and hence, Indian investors are advised to buy Metal sector scripts during the rest of the month and sell them at the first half of the month period which will yield better returns.
\end{abstract}

Keywords--- Anomalies, Turn of the Month Effect, BSE Metal Index, and Efficient Market Hypothesis

\section{INTRODUCTION}

$\mathrm{T}$ HE trend of stock prices to increase during the last two days and the first three days of each month is called the Turn of the Month Effect. For the purpose of this study, the average returns on the last two trading days of the preceding month, and the first three days of the subsequent month were computed and compared with the mean return for the rest of the days in the subsequent month. The BSE Metal Index is designed to reflect the behaviour and performance of the Metal sector including mining. India became the third largeststeelproducerin 2015 withtheproductionoftotalfinishedste elat91.46milliontonnes.Indiawas ranked the fourth largest crude steel producer in 2014. India is the third largest producer of coal with the projected production of 630.25 million tonnes inFY15. India has the world's fifth-largest coal reserves and accounts for 7.5 per cent of total global production. Its coal reserves are 301.6 billion tonnes. The country is expected to become the second largest steel producer by 2016.The metal and mining industry of India registered a strong 19.8 per cent expansion in 2011 to touch US\$ 141.9 billion and is expected to reach 305.5 billion by 2015 . India was the third largest producer of crude steel in the Asia-Pacific region in 2014. Total finished steel production in India reached 91.46 million tonnes in 2015 (http://www.ibef.org/).Its strategic location enables its exports to develop as well as the those of fast developing Asian markets. The Government of India has

J. Sudarvel, Ph.D (FT), Research Scholar, Department of Management Studies and Research, Karpagam Academy of Higher Education, Coimbatore, Tamilnadu, India. E-mail:j.sudarvel@gmail.com

Dr.R. Velmurugan, Associate Professor, Department of Commerce, Karpagam Academy of Higher Education, Coimbatore, Tamilnadu, India. E-mail:drvelsngm@gmail.com DOI: 10.9756/BIJIEMS.8132 allowed 100 per cent foreign direct investment (FDI) in the mining sector (Consolidated FDI Policy Circular of 2015http://dipp.nic.in/). Mining lease has been granted for a long duration a minimum 20 years and up to 30 years. It has also approved an MMDR Bill (2011) to provide a better legislative environment for investment and technology. The BSE Metal Index is designed to reflect the behaviour and performance of the Metals sector. The BSE Metal Index is comprised of a maximum of 10 stocks that are listed on the Bombay Stock Exchange (BSE).

\section{REVIEW OF LITERATURE}

Amy Dickinson and David R. Peterson (1995), in their study prove that the Turn of the Month Effect is at least partially anticipated in the United States. Eleftherios Giovanis (2009), in his study, found that the turn-of-the-month is persistent only in two stock indices, in Yugoslavia and Sweden. Erhard Reschenhofer (2010),in his study, strongly corroborates the existence of the Turn of the Month Effect in the S\&P 500 index. Idries M. Al-Jarrah, Basheer A. Khamees and Ibrahim Hashem Qteishat found that the Turn of the Month Effect does not significantly exhibit in Amman Stock Exchange, Jordan. Lan Liu (2013), finds that the Turn of the Month Effect still exists in the US. And investments made on the days before the Turn of the Month perform better than those made during the turn-of-the-month. Nageswari. P and Dr.M. Selvam (2011),reveal that the Turn of the Month Effect did exist in the returns of the Indian Stock Market during the study period (2002 - 2010).Neeraj Amarnani and Parth Vaidya (2014), found that the Turn of the Month Effect exists in both Sensex and Nifty. Silva. PM (2010), found that the Turn of the Month Effect records exists in the Portuguese stock market. Van der Gugten. T and D. J. C. Smant (2010), found that Turn of the Month Effect exists when ever macroeconomic news occupy the minds of the buying public.

The previous studies, researchers have dealt with the macro level BSE - Sensex and NSE - Nifty. So far researchers have not focused on sectoral indices. In order to fill this gap the present study has been carried out.

\section{Statement OF THE Problem}

Metal industry plays a predominant role in the infrastructure development of a country. Hence, Indian investors may prefer to invest their hard-earned money in metal industry shares. But, unfortunately, the returns they derive are not in accordance with their expectations. The main reason for not obtaining the expected return is the improper timing of investments. To earn the expected return, the investor should invest their money at an appropriate time. This study aims to inform the investors to park their funds at the 
appropriate time to enable them to receive a higher rate of return.

\section{Objective of the Study}

To identify the existence of the Turn of the Month Effect inthe Indian Metal sector.

\section{RESEARCH METHODOLOGY}

\section{Data}

This study is analytical in nature. The data required for the study were collected from daily closing prices of BSE Metal index.(http://www.bseindia.com/indices/IndexArchiveData.as px)

\section{Period of the Study}

The present study covers the period ranging between April 2004 and March 2015.

\section{FRAMEWORK OF ANALYSIS}

The collected data were analysed by making use of Descriptive statistics such as Mean, Standard Deviation, Variance, Skewness, Kurtosis and Shapiro-Wilk test and paired ' $t$ 'test.

\section{LIMITATION}

Considering the continuity of data, only BSE Metal Index was selected for the study. Hence, utmost care has to be exercised while generalizing the results.

\section{ANALYSIS AND INTERPRETATION}

The Turn of the month denotes the last two trading days of the previous month and the first three days of the current month and the remaining days are denoted as the rest of the month.

To find the mean returns, volatility and normality in the BSE METAL index, descriptive statistics like Mean, Standard deviation, Variance, Skewness, Kurtosis, and Shapiro-Wilk test are made use of. The following table presents the result of the descriptive study;

\section{BSE Metal Index Returns - Descriptive Statistics}

Table 1

\begin{tabular}{|l|l|l|}
\hline & $\begin{array}{l}\text { TURN OF THE MONTH } \\
\text { (FIRST HALF) }\end{array}$ & REST OF THE MONTH \\
\hline Mean & .2495 & -.0733 \\
\hline Median & .2836 & -.1056 \\
\hline Std. Deviation & 1.06839 & .72833 \\
\hline Variance & 1.141 & .530 \\
\hline Skewness & -.712 & -.783 \\
\hline Kurtosis & 3.365 & 4.367 \\
\hline Shapiro-Wilk & .000 & .000 \\
\hline Source - Database collected from BSE web portal and computed.
\end{tabular}

Thus, it is inferred from Table.1 that a high level of mean returns is noticed during the first half of the month(.2495)and a lower level mean return is found during the rest of the month(-.0733)These results complement the claims of Silva. PM (2010),Nageswari. P and Dr.M. Selvam (2011) Comparing the variance, a high level of volatility was noticed in the first half of the month (1.141) and a low level of volatility was noticed during the rest of the month(.530).

Further, the analysis of Skewness test discloses the fact that negative returns are noticed in the first half of the month and the rest of the month returns. The Kurtosis of BSE METAL index returns were found leptokurtic in both the first half of the month (3.365) and during the rest of the month (4.367). SinceKurtosis values are greater than 3 , it can be inferred that the BSE METAL index returns are leptokurtic.

As the $p$ value of Shapiro-Wilk test ofBSE METAL INDEX returns is less than 0.05 , it is clearly proved that the data are not normally distributed; there is an anomaly inthe BSE METALINDEX returns.

\section{Determinants of Turn of the Month Effect-Paired 't' test}

To determine whether the share index differs between the first half of the month and the rest of the month, paired ' $t$ ' test is employed.

\section{Determinants of Turn of the Month Effect - Paired ' $t$ ' test}

Table 2

\begin{tabular}{|l|l|l|l|l|l|}
\hline & Mean & $\mathrm{N}$ & Std. Deviation & Paired t value & P value \\
\cline { 1 - 2 } $\begin{array}{l}\text { TURN OF THE MONTH } \\
\text { (FIRST HALF) }\end{array}$ & .2495 & 132 & 1.06839 & 3.038 & .003 \\
\cline { 1 - 3 } REST OF THE MONTH & -.0733 & 132 & .72833 & & \\
\hline
\end{tabular}

As the $\mathrm{p}$ value is less than 0.01 , there exists a significant difference in returns between the first half and the rest of the month. Hence the Turn of the Month Effect prevails in the BSE Metal Index.

\section{FINDINGS OF THE STUDY}

- In BSE Metal index the highest mean return was noticed in the first half of the month, and then during the rest of the month.

- High volatility was noticed during the first half of the month.

- Skewness test discloses that negative returns are noticed in the first half and in the rest of the month returns.

- The Kurtosis of BSE Metal index returns were found leptokurtic in both the first half of the month and rest of the month.

- Shapiro-Wilk test clearly proved that the BSE Metal index data are not normally distributed.

- The paired t-test discloses that there was a significant difference between the returns of the first half of the month and the rest half of the month. Hence, it may be included that the Turn of the Month Effect does exist in the Indian Metal sector indices.

\section{SUGGESTIONS}

The study found that the highest mean returns were noticed in the first half of the month. Hence, Indian investors are advised to buy metal sector scripts during the rest of the month and sell the shares during the first half of the month, which will fetch better returns. Investors could experiment the above policy, to start with, on small stocks and extend the same on blue-chips based on the risks and rewards. 


\section{CONClusion}

The study focused on the existence of a Turn of the Month Effect in the BSE Metal index in India. The analysis of descriptive statistics displayed that the highest average return occurred in the first half of the month and found low return in the rest of the month. The calculated paired ' $t$ ' test value is statistically significant which shows that the Turn of the Month Effect does exist in the BSE metal index.

The research of the study raises questions on the efficient market hypothesis which states that stock prices are random, and that investors cannot make abnormal profits using past prices. The Semi month effect patterns in return and volatility can enable the investors to take advantage of moderately regular market shifts by manipulating and implementing trading strategies, which account for such predictable patterns. Specially, our results indicate lower returns in the rest of the month and maximum returns in the first half of the month in the BSE Metal index. So, the specific trading guideline that could be considered is that one of buying the scripts at every rest of the month (buy low) and selling the mat every first half of the month (sell high). However, this tactic needs to be implemented with caution. The researcher suggest that investors could experiment the above policy, to start with, on small stocks and extend the same on blue-chips based on the risks and rewards. This advantage may add further energy as Indian markets are more translucent and are open to the worldwide investors seeking profitable trade opportunities.

The study points out that stock returns in India Metalsector are not entirely random. This suggests that the Indian stock market may not be efficient. The Market Regulators have to better closely monitor the investors' response as regards information transmission and its dependability or the honesty of the information released by the Indian Companies. The present study may be extent to other sectors like Automobile, Banking, FMCG, IT, etc. The prevalence of stock market anomalies may be studied by ascertaining the semi month effect, Monthly effect, Day-of-the week effect and the like. Thus, research scholars may focus their attention on ascertaining the stock market anomalies by studying the Semi month effect, Monthly effect, Day-of-the week effect and the like.

\section{REFERENCES}

[1] Amy Dickinson and David R. Peterson "Expectations of Weekend and Turn-Of-The-Month Mean Return Shifts Implicit In Index Call Option Prices" Journal Of Financial And Strategic Decisions Volume 8, No: 3, Fall 1995

[2] Erhard Reschenhofer (2010) "Further Evidence on the Turn of the Month Effect"Business and Economics Journal, Volume 2010: BEJ-16

[3] Eleftherios Giovanis (2009) "Calendar Effects and Seasonality on Returns and Volatility"MPRA Paper No. 64404, posted 17. May 2015 19:37 UTC

[4] Idries M. Al-Jarrah, Basheer A. Khamees and Ibrahim Hashem Qteishat "The "Turn of the Month Anomaly" in Amman Stock Exchange: Evidence and Implications" Journal of Money, Investment and BankingISSN 1450-288X Issue 21 (2011)

[5] Lan Liu (2013) The Turn of the Month Effect In The S\&P 500 (20012011) Journal of Business \& Economics Research - June 2013 Volume 11 , Number 6

[6] NAGESWARI. P and Dr.M. Selvam (2011) "Calendar Anomalies in the Indian Stock Market" un published thesis Bharathidasan University, Tiruchirappalli.
[7] Neeraj Amarnani and Parth Vaidya "Study of Calendar Anomalies in Indian Stock Markets" (January 1, 2014). Perspectives on Financial Markets and Systems - Market Efficiency, Behavioural Finance and Financial Inclusion, (Ahmedabad, Institute of Management, Nirma University). Available at SSRN: http://ssrn.com/abstract=2398195

[8] Silva. PM (2010)"Calendar "anomalies" in the Portuguese stock market", Investment Analysts Journal - No. 71 2010(P.No 37-50)

[9] Van der Gugten. T and Dr. D. J. C. Smant (2010) "Stock Market Calendar Anomalies and Macroeconomic News Announcements" Erasmus School of Economics Erasmus University Rotterdam September 2010

[10] http://www.ibef.org/download/Metals-and-Mining-August-2015.pdf

[11] http://www.ibef.org/industry/metals-and-mining-presentation

[12] http://www.bseindia.com/indices/DispIndex.aspx?iname=METAL\&inde $x \_$Code $=35$ \&page $=150 \mathrm{~EB} 131-1 \mathrm{E} 37-4 \mathrm{CB} 4-\mathrm{B} 0 \mathrm{~A} 4-\mathrm{FE} 192200192 \mathrm{D}$

[13] https://www.edelweiss.in/Index/Snapshot.aspx?co_code=25113

[14] http://www.bseindia.com/indices/IndexArchiveData.aspx 